\title{
Extracts of leaves as corrosion inhibitors - An overview and corrosion inhibition by an aqueous extract of henna leaves (Lawsonia inermis)
}

\section{N.R. Devi, ${ }^{1}$ N. Karthiga, ${ }^{2}$ R. Keerthana, ${ }^{3}$ T. Umasankareswari, ${ }^{4}$} A. Krishnaveni, ${ }^{5}$ G. Singh $^{6}$ and S. Rajendran ${ }^{2 *}$

${ }^{1}$ Department of Zoology, GTN Arts College, Dindigul, 624005 India ${ }^{2}$ Corrosion Research Centre, Department of Chemistry, St. Antony's College of Arts and Sciences for Women, Dindigul, 624005, India (Affiliated to Mother Teresa's University, Kodaikanal, India)

${ }^{3} P G$ Department of Chemistry, M.V. Muthiah Government Arts College for Women, Dindigul, 624001, India

${ }^{4}$ Department of Chemistry, Rajapalayam Raju's College, Rajapalayam, India

${ }^{5}$ Department of Chemistry, Yadava College, Madurai, India

${ }^{6}$ Vice Chancellor, Pondicherry University, Puthucherry, India

*E-mail: susairajendran@gmail.com

\begin{abstract}
To update hazardous poisonous inhibitors, extracts of plant leaves are used as corrosion inhibitors. They are less toxic and nonpoisonous. They are inexpensive and easily, readily available in plenty. The active ingredients of these extracts contain many organic compounds along with terpenes, alkaloids etc. They in particular contain polar atoms which include oxygen, nitrogen and sulphur etc. These extracts are used to manipulate corrosion of several metals and alloys in various media along with acidic, basic and neutral. They are also used to manipulate corrosion of metals and alloys in well water and sea water. The active principle of these extracts coordinates through their polar atoms with metal ions to form metal-inhibitor complexes. They feature as protecting film. Various methods of controlling of corrosion are discussed. A case has a look at of corrosion resistance of mild steel in sea water in the presence of an aqueous extract of henna leaves is discussed. An aqueous extract of henna leaves (Lawsonia inermis) has been used as corrosion inhibitor in controlling corrosion of mild steel in well water. The inhibition efficiency has been evaluated by weight loss method. The mechanistic aspects of corrosion inhibition have been studied by electrochemical studies such as polarization study and AC impedance spectra. The protective film formed on the metal surface has been analyzed by luminescence spectra, FTIR, SEM and AFM. The protective film consists of iron-lawsone complex. The adsorption of inhibitor molecules on the metal surface obeys Langmuir adsorption isotherm.
\end{abstract}

Keywords: corrosion inhibition, green inhibitors, extract of leaves, FTIR, SEM, AFM, Langmuir adsorption isotherm, electrochemical studies.

Received: June 6, 2020. Published: October 1, 2020

doi: $10.17675 / 2305-6894-2020-9-4-2$ 


\section{Introduction}

This article consists of two sections A and B. Section A deals with "Extracts of leaves as corrosion inhibitors. An overview". Section B deals with "Corrosion inhibition by an aqueous extract of henna leaves (Lawsonia inermis)".

\section{Section A. Extracts of leaves as corrosion inhibitors. An overview}

\section{Introduction}

Various metals have been used in corrosion inhibition study. Environmentally friendly green inhibitors have been used to control corrosion of metals [1-20]. Different methods are employed to evaluate the corrosion inhibition process. The protective film has been analyzed by various surface analysis techniques. Important findings of the study are presented.

\section{Metals}

Extracts of leaves have been used to control corrosion of many metals and alloys. For example leaves extract has been used to control corrosion of mild steel $[1,2,4,5,7,10,13,14,16-20]$, steel [11], X65 steel [12], carbon steel [3, 6] and iron [9].

\section{Medium}

Usually corrosion of metals in various environments has been studied. Various media include chloride medium, sea water, acidic medium, basic medium and neutral medium. For example extract of leaves have been used to control corrosion of metals in acid medium [1$7,9,10,12-14,17-19]$ and alkaline medium $[11,20]$.

\section{Plant leaves extract as corrosion inhibitors}

Extracts of many leaves have been used as corrosion inhibitors. For example extracts of the plant Mimusaps Elangi (ME) extract [1], Ziziphora leaves extract [2], laurus nobilis extract [3], Papaver somniferum leaves/stems (called poppy) [4], Robinia pseudoacacia leaves extract (RPLE) [5], Ficus carica (FC), Olea europaea (OE) and Ziziphus spina-christi (ZSC) leaves [6], Macaranga Peltata leaves[7], Wuluh star fruit (Averrhoa bilimbi linn.) leaves extract [8], leaves of Pistacia terebinthu [9], Adina cordifolia leaves extract[10], Olive leaf extract[11], coconut leaf extract [12], Eucalyptus leaf extract [13, 14, 18, 20], zinc acetylacetonate and Urtica Dioica leaves extract[15], extracts of plant origin[16], Tamarindus Indica leaves Extract[17] and Ficus hispida leaves [19], have been used as corrosion inhibitors.

\section{Methods}

Various methods such as weight loss method [1, 6, 8, 17, 19], electrochemical studies such as polarization and $\mathrm{AC}$ impedance spectra $[1-3,5,7,9-13,18-20]$ have been employed to 
evaluate the corrosion behavior of metals and alloy in various media in presence of extracts of leaves.

\section{Surface analysis}

Corrosion inhibition is due to formation of protective film protective filmed on the metal surface. Usually the protective film consists of metal inhibitor complex formed on metal surface. For example, FTIR Spectroscopy [2, 4, 5, 10, 13, 14, 20]. SEM [1, 4, 5, 9, 10, 14, 15, 20], UV [2, 4, 20], EDX [4, 9], AFM [4, 20] and GC-MS [9, 14, 19] have been employed.

\section{Less frequently used techniques}

There are some techniques which are less commonly used and rarely used. For example, thermodynamic parameters, molecular dynamics, contact angle measurement, hardness (Vicker hardness) of metal surface before and after corrosion inhibition have not been employed frequently.

\section{Important findings}

Many important conclusions have been drawn from the inhibition studies. The main reason for corrosion protection is due to the formation of a protective film formed on the metal surface. The protective film consists of metal inhibitor complex formed on the surface of the metal.

- As the concentration of plant leaves extract increases corrosion inhibitor increases. $[1,2,7,10,15,17,19,20]$.

- The first step in the corrosion inhibition process is adsorption of inhibitor on the metal surface.

- The important isotherms are Langmuir [13, 18, 19] and Temkin [13]

- Electrochemical studies confirm the formation of protective film on the metal surface

- When a protective film in formed linear polarisation resistance increases, change transfer resistance increases, impedance value increases, corrosion current value decreases and double layer capacitance value decreases.

The various facts discussed above are summarised in the following Table 1.

Table 1. Extract of leaves used as corrosion inhibitors.

\begin{tabular}{|c|c|c|c|c|c|}
\hline No. & Metal/Medium & Inhibitor & Methods & Findings & Ref. \\
\hline 1 & $\begin{array}{l}\text { Mild steel in } \\
1 \mathrm{~N} \mathrm{HCl} \text { medium }\end{array}$ & $\begin{array}{l}\text { Various } \\
\text { parts of the } \\
\text { plant } \\
\text { Mimusaps } \\
\text { Elangi (ME) } \\
\text { extract }\end{array}$ & $\begin{array}{l}\text { Weight loss method, } \\
\text { potentiodynamic } \\
\text { polarization and } \\
\text { electrochemical } \\
\text { impedance } \\
\text { spectroscopy and SEM }\end{array}$ & $\begin{array}{l}\text { The inhibition efficiency (IE) } \\
\text { of ME extracts increases with } \\
\text { increase in concentration. This } \\
\text { is supported by the results of } \\
\text { electrochemical studies. }\end{array}$ & 1 \\
\hline
\end{tabular}




\begin{tabular}{|c|c|c|c|c|c|}
\hline No. & Metal/Medium & Inhibitor & Methods & Findings & Ref. \\
\hline & & & & $\begin{array}{c}\text { Maximum inhibition efficiency } \\
\text { was found to be } 98.50 \%\end{array}$ & \\
\hline 2 & Mild steel in $\mathrm{HCl}$ & $\begin{array}{c}\text { Ziziphora } \\
\text { leaves } \\
\text { extract }\end{array}$ & $\begin{array}{l}\text { FT-IR spectroscopy } \\
\text { Ultraviolet-Visible } \\
\text { (UV-Vis) } \\
\text { spectroscopy, and } \\
\text { electrochemical } \\
\text { impedance } \\
\text { spectroscopy (EIS) }\end{array}$ & $\begin{array}{l}\text { The inhibition performance } \\
\text { rises to } 93 \% \text {. The Ziziphora } \\
\text { leaves extract molecules } \\
\text { adsorption on the steel surface } \\
\text { occurs according to the } \\
\text { Langmuir isotherm model }\end{array}$ & 2 \\
\hline 3 & $\begin{array}{l}\text { Carbon steel in } \\
\text { acidic solution }\end{array}$ & $\begin{array}{l}\text { Laurus } \\
\text { nobilis } \\
\text { extract }\end{array}$ & $\begin{array}{c}\text { potentiodynamic } \\
\text { polarization and EIS }\end{array}$ & $\begin{array}{l}\text { Nobilis leaves extract offers the } \\
\text { maximum protection } \\
\text { performance of } 92 \% \text {. Cathodic } \\
\text { reaction controlled } \\
\text { predominantly }\end{array}$ & 3 \\
\hline 4 & $\begin{array}{l}\text { Mild steel in } \\
\text { acidic medium }\end{array}$ & $\begin{array}{c}\text { Papaver } \\
\text { somniferu } \\
\quad m \\
\text { leaves/ste } \\
\text { ms (called } \\
\text { poppy) }\end{array}$ & $\begin{array}{c}\text { FE-SEM, EDX, } \\
\text { AFM, CA } \\
\text { measurements, FT- } \\
\text { IR, GIXRD, UV-Vis } \\
\text { spectroscopy were } \\
\text { carried out }\end{array}$ & $\begin{array}{l}\text { Protective complexes formed } \\
\text { on metal surface. The } \\
\text { magnificent inhibition of } \\
\text { around } 97.64 \% \text { was reached }\end{array}$ & 4 \\
\hline 5 & $\begin{array}{l}\text { Mild steel in } \\
\text { acidic medium }\end{array}$ & $\begin{array}{l}\text { Robinia } \\
\text { pseudoaca } \\
\text { cia leaves } \\
\text { extract } \\
\text { (RPLE) }\end{array}$ & $\begin{array}{l}\text { Electrochemical } \\
\text { techniques, FTIR, } \\
\text { SEM, and } \\
\text { thermodynamic } \\
\text { parameter is used }\end{array}$ & $\begin{array}{l}\text { The inhibition efficiencies have } \\
\text { decreased with increasing } \\
\text { temperature while the } \\
\text { activation energy value } \\
\text { increases with the addition of } \\
\text { RPLE to acidic solution }\end{array}$ & 5 \\
\hline 6 & $\begin{array}{l}\text { Carbon steel in } \\
\text { sulfuric acid } \\
\text { medium }\end{array}$ & $\begin{array}{c}\text { Ficus } \\
\text { carica } \\
\text { (FC), Olea } \\
\text { europaea } \\
\text { (OE) and } \\
\text { Ziziphus } \\
\text { spina- } \\
\text { christi } \\
\text { (ZSC) } \\
\text { leaves }\end{array}$ & $\begin{array}{l}\text { Weight loss method. } \\
\text { Temperature studies }\end{array}$ & $\begin{array}{c}\text { The order of inhibition } \\
\text { efficiency as Olea } \\
\text { europaea }>\text { Ficus carica } \\
\text { (FC) > Ziziphus spina-christi } \\
\text { (ZSC). Langmuir adsorption } \\
\text { isotherm obeyed }\end{array}$ & 6 \\
\hline 7 & $\begin{array}{l}\text { Mild Steel in } \\
\text { Hydrochloric } \\
\text { Acid Medium }\end{array}$ & $\begin{array}{c}\text { Macarang } \\
\text { a Peltata } \\
\text { leaves }\end{array}$ & $\begin{array}{l}\text { Weight loss method } \\
\text { and electrochemical } \\
\text { methods } \\
\text { and thermodynamic } \\
\text { parameters }\end{array}$ & $\begin{array}{l}\text { The inhibition efficiency } \\
\text { increased with an increase in } \\
\text { the inhibitor concentration and } \\
\text { temperature and obeyed the } \\
\text { Langmuir adsorption isotherm }\end{array}$ & 7 \\
\hline
\end{tabular}




\begin{tabular}{|c|c|c|c|c|c|}
\hline No. & Metal/Medium & Inhibitor & Methods & Findings & Ref. \\
\hline 8 & $\begin{array}{l}\text { Reinforced steel } \\
\text { in corrosive } \\
\text { medium }\end{array}$ & $\begin{array}{l}\text { Wuluh star } \\
\text { fruit } \\
\text { (Averrhoa } \\
\text { bilimbi } \\
\text { linn.) } \\
\text { leaves } \\
\text { extract }\end{array}$ & Weight loss method & $\begin{array}{l}\text { The study results shown that } \\
\text { the extract of Wuluh star was } \\
\text { able to inhibit the corrosion } \\
\text { rate as } 0.0004 \mathrm{~cm} / \mathrm{y} \text { at the } \\
\text { optimum inhibitor volume of } \\
16 \mathrm{~mL} \text { with the efficiency of } \\
99.7 \%\end{array}$ & 8 \\
\hline 9 & $\begin{array}{l}\text { Iron in a } 3 \% \\
\mathrm{NaCl} \text { solution }\end{array}$ & $\begin{array}{l}\text { leaves of } \\
\text { Pistacia } \\
\text { terebinthus }\end{array}$ & $\begin{array}{c}\text { gravimetric } \\
\text { measurements and } \\
\text { electrochemical } \\
\text { methods, GC-MS, } \\
\text { SEM and EDX }\end{array}$ & $\begin{array}{l}\text { The results obtained at } \\
200 \mathrm{ppm} \text { are very interesting, } \\
\text { and reach maximum values of } \\
96.96 \%, 89 \% \text { and } 64.82 \%, \\
\text { respectively, and good } \\
\text { corrosion resistance }\end{array}$ & 9 \\
\hline 10 & $\begin{array}{l}\text { Mild steel } \\
\text { corrosion in } \\
0.5 \mathrm{M} \text { sulphuric } \\
\text { acid medium }\end{array}$ & $\begin{array}{l}\text { Adina } \\
\text { cordifolia } \\
\text { leaves } \\
\text { extract } \\
\text { (ACLE) }\end{array}$ & $\begin{array}{l}\text { Weight loss method, } \\
\text { electrochemical } \\
\text { studies and SEM, } \\
\text { FTIR }\end{array}$ & $\begin{array}{l}\text { The ACLE increases the } \\
\text { charge transfer resistance and } \\
\text { decreases double layer } \\
\text { capacitance and the formation } \\
\text { of ACLE protective film } \\
\text { protects MS }\end{array}$ & 10 \\
\hline 11 & $\begin{array}{l}\text { Steel in alkaline } \\
\text { medium }\end{array}$ & $\begin{array}{l}\text { Olive leaf } \\
\text { extract }\end{array}$ & $\begin{array}{l}\text { Electrochemical } \\
\text { techniques and Mott- } \\
\text { Schottky analyses }\end{array}$ & $\begin{array}{l}\text { The best inhibition of } 91.9 \% \text { is } \\
\text { provided with methanol } \\
\text { extract. GC-MS analysis } \\
\text { showed the presence of } \\
\text { compounds containing the } \\
\text { heteroatoms } \mathrm{N} \text { and } \mathrm{O} \text { with the } \\
\pi \text { electrons which are } \\
\text { responsible for the corrosion } \\
\text { inhibition activity }\end{array}$ & 11 \\
\hline 12 & $\begin{array}{l}\text { X65 steel in } \\
\text { hydrochloric acid } \\
\text { solution }\end{array}$ & $\begin{array}{c}\text { Coconut } \\
\text { leaf extract }\end{array}$ & $\begin{array}{l}\text { electrochemical } \\
\text { studies, surface } \\
\text { morphology analysis, } \\
\text { and theoretical } \\
\text { calculations }\end{array}$ & $\begin{array}{l}\text { Surface morphology analysis } \\
\text { test results showed that } \\
\text { coconut leaf extract can } \\
\text { effectively inhibit the corrosion } \\
\text { of X65 steel. The adsorption of } \\
\text { coconut leaf extract on the X65 } \\
\text { steel surface conforms to the } \\
\text { Langmuir single layer } \\
\text { adsorption }\end{array}$ & 12 \\
\hline 13 & $\begin{array}{l}\text { Mild steel in } \\
\text { sulfuric and } \\
\text { phosphoric acid } \\
\text { solutions }\end{array}$ & $\begin{array}{l}\text { Eucalyptus } \\
\text { leaf extract }\end{array}$ & $\begin{array}{l}\text { Potentiodynamic } \\
\text { polarization curves } \\
\text { measurements and } \\
\text { EIS, FTIR, Four } \\
\text { adsorption isotherms } \\
\text { including Langmuir, }\end{array}$ & $\begin{array}{l}\text { The corrosion process occurs } \\
\text { under activation control. } \\
\text { Eucalyptus leaf extract is a } \\
\text { more efficient inhibitor of mild } \\
\text { steel corrosion in sulfuric and } \\
\text { phosphoric acid solutions }\end{array}$ & 13 \\
\hline
\end{tabular}




\begin{tabular}{|c|c|c|c|c|c|}
\hline No. & Metal/Medium & Inhibitor & Methods & Findings & Ref. \\
\hline \multicolumn{6}{|c|}{$\begin{array}{c}\text { kinetic- } \\
\text { thermodynamic, } \\
\text { Flory-Huggins and } \\
\text { Temkin model }\end{array}$} \\
\hline 14 & $\begin{array}{l}\text { Mild steel in } \\
\text { hydrochloric acid }\end{array}$ & $\begin{array}{l}\text { Eucalyptus } \\
\text { leaf extract }\end{array}$ & $\begin{array}{c}\text { FTIR } \\
\text { Spectrophotometer, } \\
\text { SEM and GC-MS are } \\
\text { used }\end{array}$ & $\begin{array}{c}\text { The optimum IE of } 87.89 \% \\
\text { was obtained. The inhibitor } \\
\text { adsorption on MS followed } \\
\text { Langmuir isotherm and } \\
\text { pseudo-second-order } \\
\text { adsorption kinetics }\end{array}$ & 14 \\
\hline 15 & $\begin{array}{l}\text { Dual } \\
\text { active/barrier } \\
\text { anti-corrosion } \\
\text { performance }\end{array}$ & $\begin{array}{c}\text { zinc } \\
\text { acetylaceto } \\
\text { nate and } \\
\text { Urtica } \\
\text { Dioica } \\
\text { leaves } \\
\text { extract }\end{array}$ & $\begin{array}{c}\text { X-ray photoelectron } \\
\text { spectroscopy (XPS), } \\
\text { (SEM), energy- } \\
\text { dispersive X-ray } \\
\text { spectroscopy (EDS), } \\
\text { (EIS) and neutral salt } \\
\text { spray (NSS) test. }\end{array}$ & $\begin{array}{l}\text { The effectiveness of the } \\
\text { pigmentation in corrosion } \\
\text { protection activity } \\
\text { improvement. A inhibition } \\
\text { efficiency (IE\%) of about } \\
99.995 \% \text { was achieved }\end{array}$ & 15 \\
\hline 16 & Mild steel & $\begin{array}{l}\text { extracts of } \\
\text { plant } \\
\text { origin }\end{array}$ & $\begin{array}{c}\text { Corrosion and } \\
\text { adsorption properties } \\
\text { with good results. } \\
\text { The findings from } \\
\text { these research works } \\
\text { provide evidence of } \\
\text { the adsorption } \\
\text { behavior of green } \\
\text { inhibitors }\end{array}$ & $\begin{array}{l}\text { It concludes that plant DNA is } \\
\text { a promising candidate for } \\
\text { green corrosion inhibitor given } \\
\text { the similarity between the plant } \\
\text { and animal DNA structure and } \\
\text { function, and the fact that the } \\
\text { use of plant is } \\
\text { more environmentally } \\
\text { sustainable than animal-based } \\
\text { product }\end{array}$ & 16 \\
\hline 17 & $\begin{array}{l}\text { Mild steel in } \\
\text { hydrochloric acid }\end{array}$ & $\begin{array}{l}\text { Tamarindu } \\
\text { s Indica } \\
\text { leaves } \\
\text { Extracts }\end{array}$ & $\begin{array}{c}\text { Weight loss } \\
\text { technique. } \\
\text { Thermodynamics } \\
\text { parameters calculated }\end{array}$ & $\begin{array}{l}\text { The inhibition efficiency of the } \\
\text { inhibitor was inversely } \\
\text { proportional to the } \\
\text { temperature, but directly } \\
\text { proportional to the } \\
\text { concentration of inhibitor. The } \\
\text { data obtained fitted in the } \\
\text { Langmuir and Temkin } \\
\text { adsorption isotherms at lower } \\
\text { temperatures }\end{array}$ & 17 \\
\hline 18 & $\begin{array}{l}\text { Mild steel (MS) } \\
\text { corrosion in the } \\
\text { HCl }\end{array}$ & $\begin{array}{l}\text { Eucalyptus } \\
\text { leaves } \\
\text { extract } \\
\text { (ELE) }\end{array}$ & $\begin{array}{l}\text { EIS and polarization } \\
\text { study }\end{array}$ & $\begin{array}{l}\text { The increase of ELE } \\
\text { concentration led to the } \\
\text { significant increment of charge } \\
\text { transfer resistance. An } \\
\text { inhibition efficiency of } \sim 88 \% \\
\text { was obtained }\end{array}$ & 18 \\
\hline
\end{tabular}




\begin{tabular}{|c|c|c|c|c|c|}
\hline No. & Metal/Medium & Inhibitor & Methods & Findings & Ref. \\
\hline 19 & $\begin{array}{c}\text { Mild steel } \\
\text { corrosion in } 1 \mathrm{M} \\
\mathrm{HCl} \text { solution }\end{array}$ & $\begin{array}{l}\text { Ficus } \\
\text { hispida } \\
\text { leaves }\end{array}$ & $\begin{array}{l}\text { Weight loss } \\
\text { measurement as well } \\
\text { as electrochemical } \\
\text { studies, Gas } \\
\text { Chromatography- } \\
\text { Mass Spectrometry } \\
\text { (GC-MS) }\end{array}$ & $\begin{array}{l}\text { Inhibition efficiency of } 90 \% \\
\text { was achieved. Temperature } \\
\text { studies revealed an increase in } \\
\text { inhibition efficiency with } \\
\text { decrease in temperature and } \\
\text { activation energies increased in } \\
\text { the presence of the extract }\end{array}$ & 19 \\
\hline 20 & $\begin{array}{l}\text { Mild steel in } \\
\mathrm{NaCl} \text { solution }\end{array}$ & $\begin{array}{c}\text { Eucalyptus } \\
\text { leaves } \\
\text { extract }\end{array}$ & $\begin{array}{c}\text { (UV-Vis), (SEM), } \\
\text { energy dispersive } \\
\text { spectroscopy (EDS), } \\
\text { (AFM), grazing } \\
\text { incidence X-ray } \\
\text { diffraction (GIXRD), } \\
\text { (FTIR) spectroscopy } \\
\text { and contact angle } \\
\text { (CA) measurements, } \\
\text { EIS and } \\
\text { potentiodynamic } \\
\text { spectroscopy (PDS) }\end{array}$ & $\begin{array}{l}\text { The efficiency in this sample } \\
\text { reached } 90 \% \text {. This } \\
\text { performance is credited to the } \\
\text { hydrophobic complexes and } \\
\text { chelates formed on the surface } \\
\text { of the substrate }\end{array}$ & 20 \\
\hline
\end{tabular}

\section{Section B. Inhibition of corrosion of mild steel in well water in presence of an aqueous extract of henna leaves (Lawsonia inermis) - A case study}

\section{Introduction}

An aqueous extract of henna leaves (Lawsonia inermis) was prepared by grinding $10 \mathrm{~g}$ of the shade dried henna leaves with water and filtering the suspended impurities and making up to $100 \mathrm{ml}$ in a standard measuring flask. The extract was used to control the corrosion of mild steel in presence of well water (WW). The findings will be useful in cooling water systems. These inhibitors may be added to cooling water carried by pipelines made of mild steel. The inhibition efficiency of the inhibitor system was evaluated by weight loss method. The mechanistic aspects were studied by polarization study and AC impedance spectra. The protective film has been analyzed by various surface analysis techniques.

\section{Experimental}

\section{Weight loss method}

\section{Preparation of Specimens}

Mild steel specimens of dimensions $1.0 \times 4.0 \times 0.2 \mathrm{~cm}$, were polished to mirror finish, degreased with trichloroethylene, and used for the weight loss method and for surface 
examination studies. Composition of mild steel was: mild steel contains carbon $0.1 \%$, manganese $0.4 \%$, and phosphorus $0.06 \%$ and rest iron.

Weights of the polished mild steel specimens were determined before and after immersion in various test solutions. The inhibition efficiencies were calculated from the relation $I E=\left[\left(W_{1}-W_{2}\right) / W_{1}\right] \cdot 100 \%$, where $W_{1}$ is corrosion rate in the absence of inhibitor and $W_{2}$ is the corrosion rate in the presence of inhibitor.

\section{Preparation of henna leaves extract as corrosion inhibitor}

An aqueous extract of henna (Lawsonia inermis) leaves was prepared by grinding $10 \mathrm{~g}$ of the shade dried henna leaves with water and filtering the suspended impurities and making up to $100 \mathrm{ml}$ in a standard measuring flask. The extract was used to control the corrosion of mild steel in presence of well water (WW).

\section{Electrochemical studies}

Corrosion resistance of mild steel immersed in various test solutions was measured by Polarization study and AC impedance spectra.

\section{Polarization study}

Polarization studies were carried out in a CHI Electrochemical work station/analyzer, model 660A. It was provided with automatic iR compensation facility. A three electrode cell assembly was used (Scheme 1).

The working electrode was mild steel. A SCE was the reference electrode. Platinum was the counter electrode. A time interval of 5 to 10 minutes was given for the system to attain a steady state open circuit potential. The working electrode and the platinum electrode were immersed in well water in the absence and presence of inhibitor. From polarization study, corrosion parameters such as corrosion potential $\left(E_{\text {corr }}\right)$, corrosion current $\left(I_{\text {corr }}\right)$, Tafel slopes anodic $=b_{\mathrm{a}}$ and cathodic $=b_{\mathrm{c}}$ and LPR (linear polarization resistance) value were calculated.

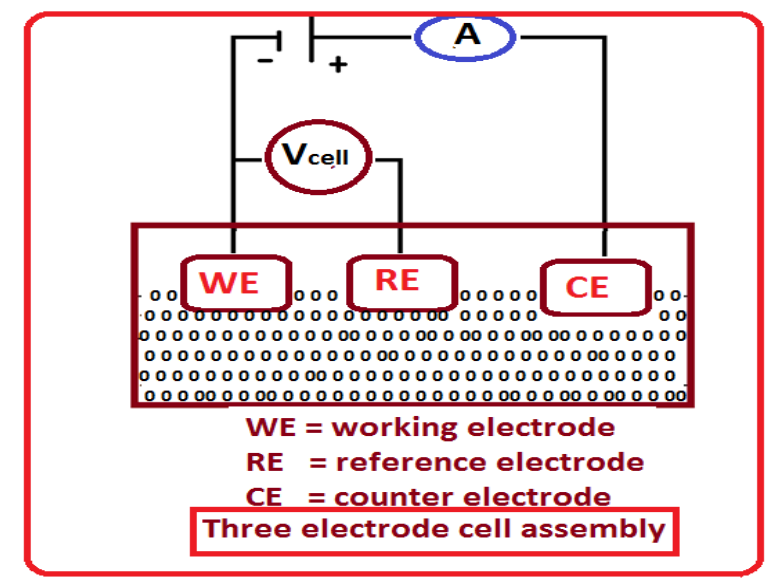

Scheme 1. Three electrode cell assembly. 


\section{AC Impedance spectra}

The same instrument and set-up used for polarization study was used to record AC impedance spectra also. The real part $\left(Z^{\prime}\right)$ and imaginary part $\left(Z^{\prime \prime}\right)$ of the cell impedance were measured in ohms at various frequencies. From AC impedance spectra Nyquist plots and Bode plots were derived. From Nyquist plot the Values of charge transfer resistance $\left(R_{\mathrm{t}}\right)$ and the double layer capacitance $\left(C_{\mathrm{dl}}\right)$ were calculated. From Bode plots impedance values were determined.

Surface analysis of protective film

Mild steel specimen was immersed in the inhibitor system for a period of one day. After one day the specimen was taken out, dried and subjected to various surface analysis techniques.

- FTIR spectra were recorded in Perkin-Elmer make, model spectrum two.

- SEM images were recorded in Cartizers make model EVO-18.

- UV visible spectra were recorded in Systronics double beam UV-VIS Spectrophotometer 2202.

- Fluorescence spectra were recorded in Shimadzu Spectrofluorophotometer.

Well water

The composition of well water used in this study is given in Table 2. The well water was collected at Dindigul, Tamil Nadu, India.

Table 2. Physicochemical parameters of well water (Dindigul, Tamil Nadu, India).

\begin{tabular}{cc}
\hline Physicochemical parameters & Quantity \\
\hline Total dissolved solid $(\mathrm{ppm})$ & 1204 \\
Conductivity micro mho/cm & 1770 \\
$\mathrm{pH}$ & 7.8 \\
Total hardness as $\mathrm{CaCO}_{3}(\mathrm{ppm})$ & 402 \\
\hline Calcium $(\mathrm{Ca})(\mathrm{ppm})$ & 88 \\
Magnesium $(\mathrm{Mg})(\mathrm{ppm})$ & 63 \\
Chloride $(\mathrm{Cl})(\mathrm{ppm})$ & 665 \\
Sulphate $\left(\mathrm{SO}{ }_{4}^{2-}\right)(\mathrm{ppm})$ & 214 \\
Sodium $(\mathrm{Na})(\mathrm{ppm})$ & 172 \\
Potassium $(\mathrm{K})(\mathrm{ppm})$ & 55 \\
\hline
\end{tabular}




\section{Results and Discussion}

Corrosion inhibition of mild steel in well water medium in presence of an aqueous extract of henna leaves (AEHL)

Corrosion inhibition of mild steel in well water medium in presence of an aqueous extract of henna leaves (AEHL) has been examined by the following techniques

- Weight loss method

- Polarization study

- AC impedance spectra

- UV-Visible absorption spectra

- Fluorescence spectra

- FTIR spectra

- SEM studies

- AFM studies

Analysis of results of weight loss method

Inhibition efficiencies of an aqueous extract of henna leaves (Lawsonia inermis) in controlling corrosion of mild steel in sea water, obtained by weight loss method are given in Table 3 .

Table 3. Inhibition efficiencies of an aqueous extract of henna leaves in controlling corrosion of mild steel in sea water, obtained by weight loss method.

\begin{tabular}{ccc}
\hline Volume of extract, $\mathbf{m l}$ & Corrosion rate, mdd & IE\% \\
\hline 0 & 32.68 & - \\
2 & 16.34 & 50 \\
4 & 12.74 & 61 \\
6 & 8.82 & 73 \\
8 & 4.9 & 85 \\
10 & 1.3 & 96 \\
\hline
\end{tabular}

Table 4. Volume of extract $v s C / \theta$.

\begin{tabular}{ccc}
\hline Volume of extract, $\mathbf{m l}(\boldsymbol{C})$ & Surface coverage, $\boldsymbol{\theta}$ & $\boldsymbol{C} / \boldsymbol{\theta}$ \\
\hline 2 & 0.50 & 4.00 \\
4 & 0.61 & 6.56 \\
6 & 0.73 & 8.22 \\
8 & 0.85 & 9.41 \\
10 & 0.96 & 10.42 \\
\hline
\end{tabular}




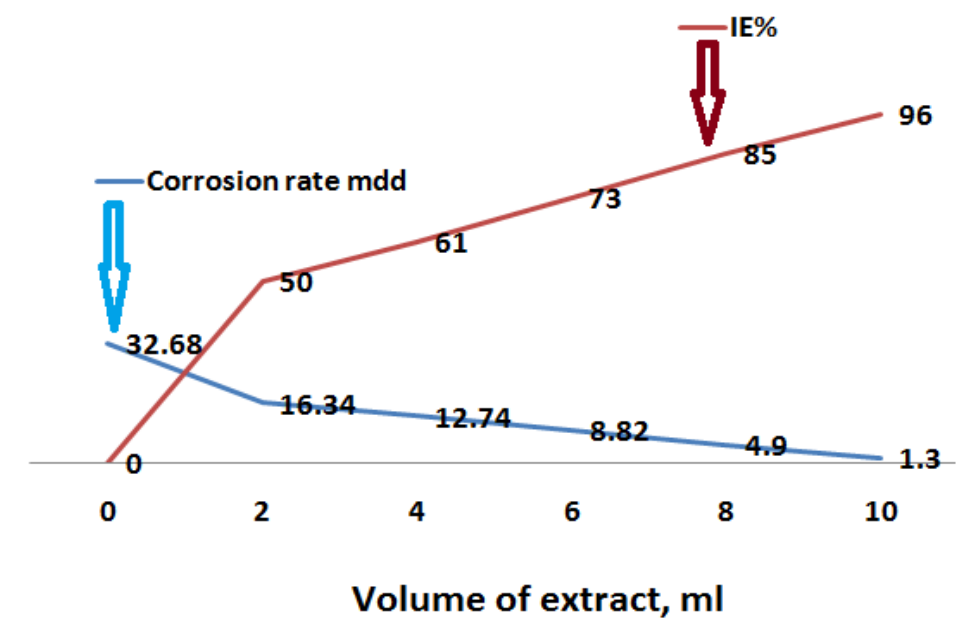

Figure 1. Inhibition efficiencies of an aqueous extract of henna leaves in controlling corrosion of mild steel in sea water, obtained by weight loss method.

It is observed from the Table 3 that as the volume of inhibitor solution increases, the corrosion rate decreases and the corrosion inhibition efficiency increases. The active ingredient of henna leaves extract, namely lawsone has joined with ferrous ion on the mild steel surface and forms a protective layer. The protective layer probably consists of ironlawsone complex and thereby the anodic reaction is hindered. Hence corrosion of mild steel is controlled.

\section{Langmuir adsorption isotherm}

Usually the corrosion inhibition by inhibitors is due to adsorption of inhibitor molecules on the metal surface. In the present study when a plot is made $C v s C / \theta$, a straight line is obtained with high R2 value (0.962). This indicates the adsorption of lawsone molecules on the metal surface obeys, Langmuir adsorption isotherm. It is to be noted that $C$ is the volume of inhibitor and $C / \theta$ is surface coverage (Table 4, Figure 2).

\section{Analysis of polarization study}

Polarization study has been employed to confirm the formation of protective coating on the mild steel surface [21-25]. If a protective layer is formed, the linear polarization resistance (LPR) value increases and the corrosion current $\left(I_{\text {corr }}\right)$ value decreases. The polarization curves of mild steel immersed in different environments are shown in Figure 3.

The polarization parameters such as corrosion potential $\left(E_{\text {corr }}\right)$ value, corrosion current $\left(I_{\text {corr }}\right)$ value, linear polarization resistance $(\mathrm{LPR})$ value and Tafel slopes $\left(b_{\mathrm{c}}=\right.$ cathodic slope and $b_{\mathrm{a}}=$ anodic slope) are calculated from the polarization curves. The values are given in Table 5. 


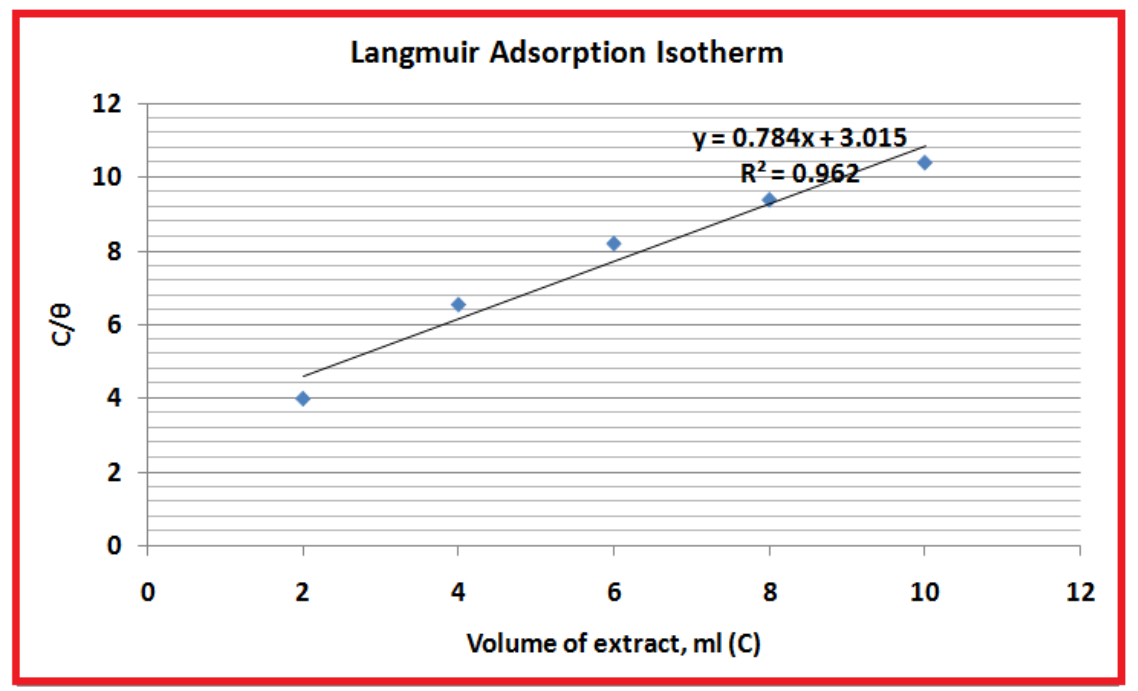

Figure 2. Langmuir adsorption isotherm.

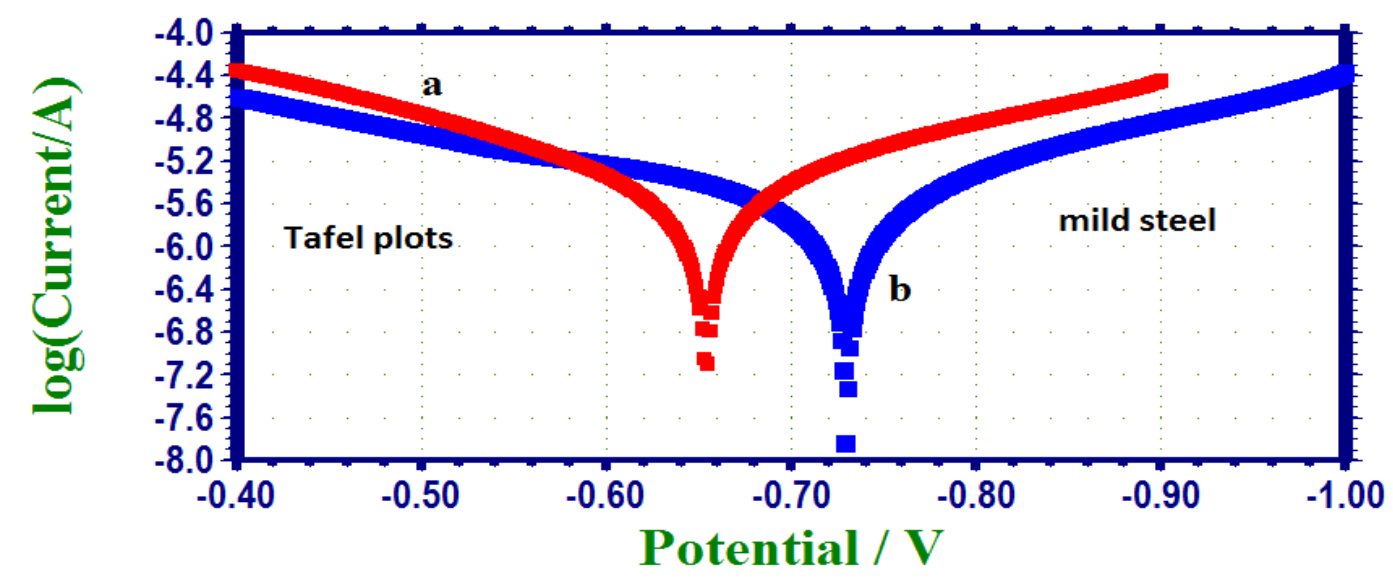

Figure 3. Polarization curves of mild steel in different environments: (a) Well water, (b) well water and extract.

Table 5. Polarization parameters of mild steel immersed in different test solutions.

\begin{tabular}{cccccc}
\hline System & $\begin{array}{c}\boldsymbol{E}_{\text {corr, }} \\
\mathbf{m V} \text { vs SCE }\end{array}$ & $\boldsymbol{I}_{\text {corr }} \mathbf{A} / \mathbf{c m}^{2}$ & $\begin{array}{c}\mathbf{L P R}, \\
\mathbf{O h m} \cdot \mathbf{c m}^{2}\end{array}$ & $\begin{array}{c}\boldsymbol{b}_{\mathbf{c}}, \\
\mathbf{m V} / \mathbf{d e c a d e}\end{array}$ & $\begin{array}{c}\boldsymbol{b}_{\text {a, }} \\
\mathbf{m V} / \mathbf{d e c a d e}\end{array}$ \\
\hline $\begin{array}{c}\text { Well water } \\
\text { Well }\end{array}$ & -654 & $9.447 \times 10^{-6}$ & 4022.1 & 181.6 & 168.4 \\
$\begin{array}{c}\text { Water + 10 ml of } \\
\text { inhibitor (extract) }\end{array}$ & -730 & $2.64 \times 10^{-6}$ & 16946.5 & 170.1 & 260.1 \\
\hline
\end{tabular}


It is noted from the Table 5 that while mild steel is immersed in well water, the corrosion potential $\left(E_{\text {corr }}\right)$ value is $-654 \mathrm{mV}$ vs SCE. The corrosion current $\left(I_{\text {corr }}\right)$ value is $9.447 \times 10^{-6} \mathrm{~A} / \mathrm{cm}^{2}$. The linear polarization resistance (LPR) value is $4022.1 \mathrm{Ohm} \cdot \mathrm{cm}^{2}$.

Upon addition of $10 \mathrm{ml}$ of inhibitor to well water medium the corrosion potential $\left(E_{\text {corr }}\right)$ value is shifted from -654 to $-730 \mathrm{mV}$ vs SCE. This kind of shift is known as cathodic shift. It reveals that the cathodic reaction occurring in mild steel surface is reduced to the maximum extent.

The linear polarization resistance (LPR) value enhances from 4022.1 to $16946.5 \mathrm{Ohm} \cdot \mathrm{cm}^{2}$ (Figure 4). The corrosion current $\left(I_{\text {corr }}\right)$ value decrease from $9.447 \times 10^{-6}$ to $2.64 \times 10^{-6} \mathrm{~A} / \mathrm{cm}^{2}$.The results confirm that a protective layer is formed on the mild steel surface. Hence the corrosion of mild steel is controlled.

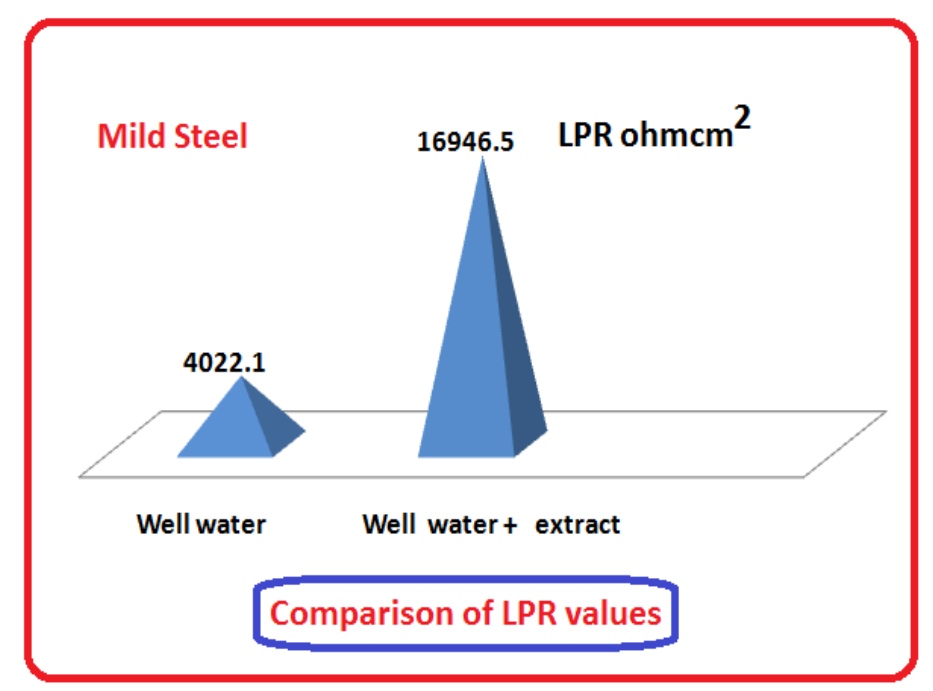

Figure 4. Comparison of LPR values.

\section{Analysis of AC impedance spectra}

AC impedance spectra make available information about the formation of protective layer on the mild steel surface [26-30]. If a protective layer is formed on the mild steel surface, the charge transfer resistance $\left(R_{\mathrm{t}}\right)$ value increases; double layer capacitance $\left(C_{\mathrm{dl}}\right)$ value decreases and the impedance $[\log (\mathrm{z} / \mathrm{Ohm})]$ value enhances. The AC impedance spectra of mild steel immersed in well water medium in presence of inhibitor are shown in Figures 57. The Nyquist plot and the Bode plots are shown in Figure 5 and Figure 6, 7 respectively. The corrosion parameters, namely the charge transfer resistance $\left(R_{\mathrm{t}}\right)$, double layer capacitance value $\left(C_{\mathrm{dl}}\right)$ and impedance $[\log (\mathrm{z} / \mathrm{Ohm})]$ value are summarized in Table 6. 


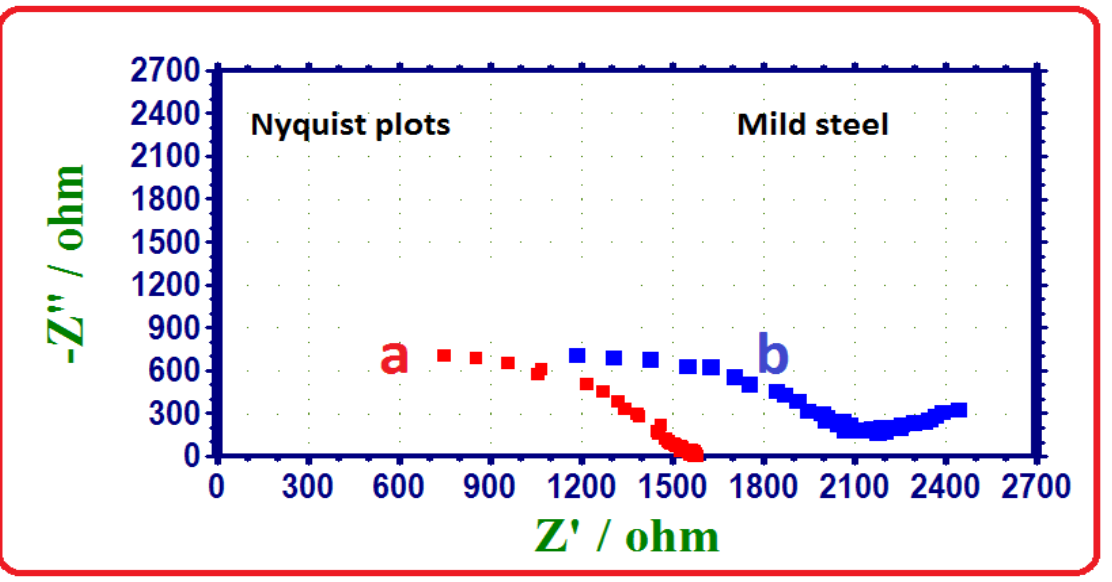

Figure 5. AC impedance spectra of mild steel in different environments (Nyquist Plots): (a) well water (Blank), (b) well water and inhibitor (extract).

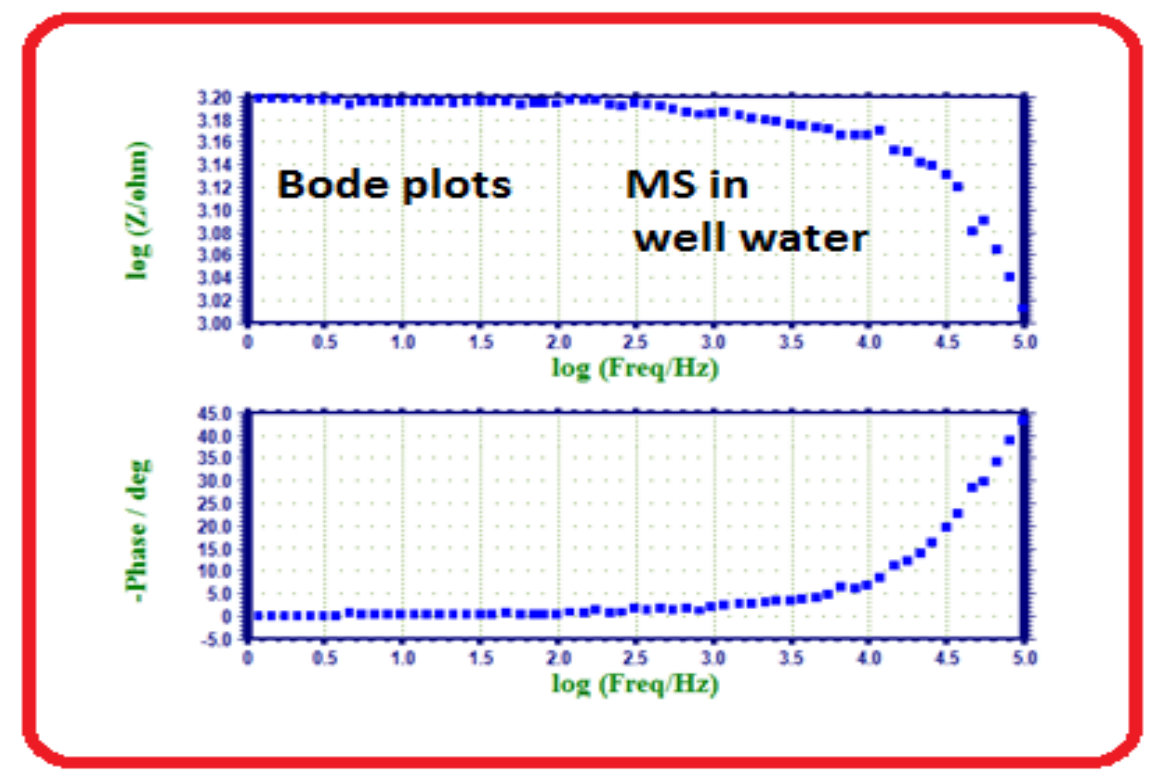

Figure 6. Bode Plots: AC impedance spectra of mild steel in well water medium (Blank).

Table 6. Corrosion parameters of mild steel in different environments calculated from AC impedance spectra.

\begin{tabular}{cccc}
\hline \multirow{2}{*}{ System } & \multicolumn{2}{c}{ Nyquist plot } & Bode plot \\
\cline { 2 - 4 } & $R_{\mathrm{t}, \mathrm{Ohm} \cdot \mathrm{cm}^{2}}$ & $C_{\mathrm{dl}, \mathrm{F} \cdot \mathrm{cm}^{-2}}$ & Impedance, $\log (Z / \mathrm{Ohm})$ \\
\hline $\begin{array}{c}\text { well water (blank) } \\
\text { well water + inhibitor } \\
\text { (extract) }\end{array}$ & 286.7 & $17.739 \times 10^{-9}$ & 2.721 \\
\hline
\end{tabular}



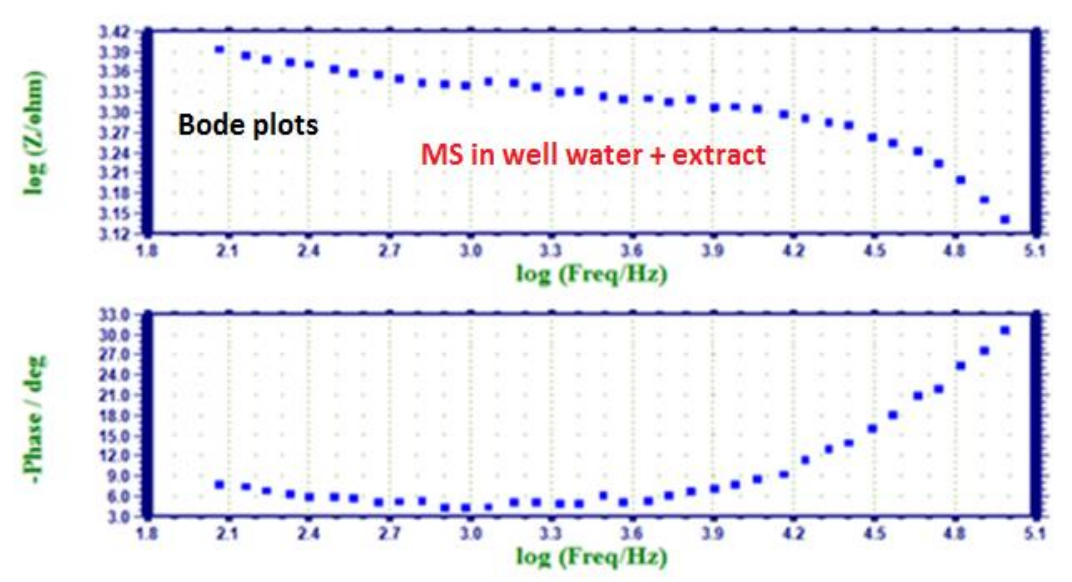

Figure 7. Bode Plots: AC impedance spectra of mild steel in well water + inhibitor (AEHL).

It is noticed from the Table 6 that when mild steel is immersed in well water, the charge transfer resistance $\left(R_{\mathrm{t}}\right)$ value is $286.7 \mathrm{Ohm} \cdot \mathrm{cm}^{2}$. The double layer capacitance $\left(C_{\mathrm{dl}}\right)$ value is $17.739 \times 10^{-9} \mathrm{~F} \cdot \mathrm{cm}^{-2}$. The impedance $[\log (Z / \mathrm{Ohm})]$ value is 2.721 . In the presence of inhibitor, the charge transfer resistance $\left(R_{\mathrm{t}}\right)$ value increases from $286.7 \mathrm{Ohm} \cdot \mathrm{cm}^{2}$ to $1329 \mathrm{Ohm} \cdot \mathrm{cm}^{2}$ (Figure 8). The double layer capacitance $\left(C_{\mathrm{dl}}\right)$ value decreases from $17.739 \times 10^{-9} \mathrm{~F} \cdot \mathrm{cm}^{-2}$ to $3.7622 \times 10^{-9} \mathrm{~F} \cdot \mathrm{cm}^{-2}$. The impedance $\log (Z / O h m)$ value enhances from 2.721 to 3.395 . The results conclude that a protective layer is formed on the mild steel surface. It restricts the flow of electrons from the mild steel to the medium. Hence corrosion of mild steel is controlled.

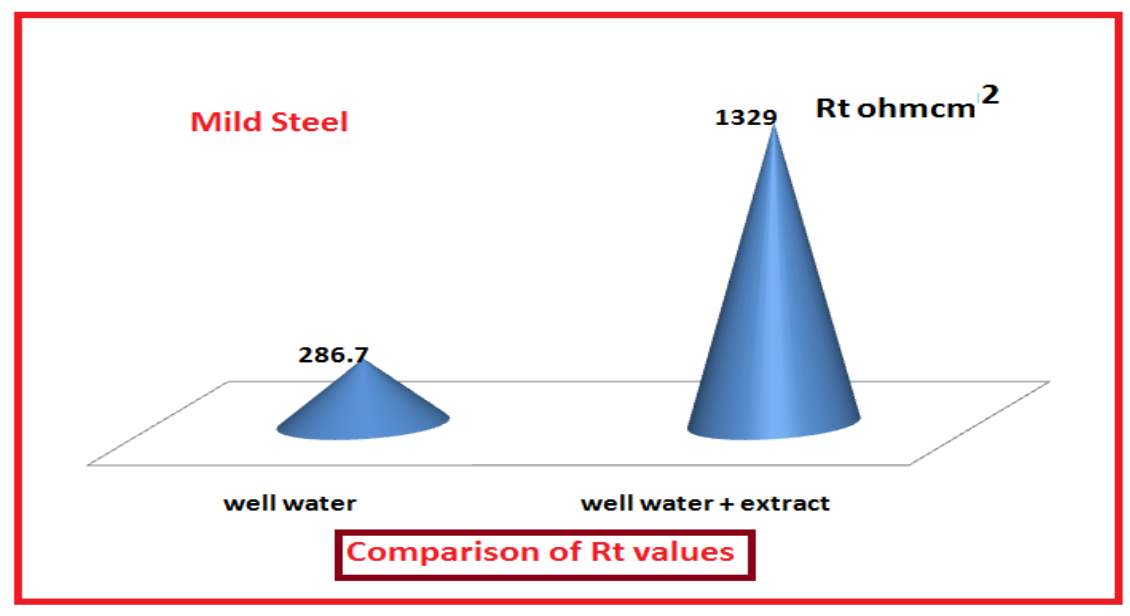

Figure 8. Comparison of $R_{\mathrm{t}}$ values. 
Analysis of UV-Visible absorption spectra

UV-Visible absorption spectra have been extensively used in corrosion inhibition studies [31]. The UV-Visible absorption spectrum of an aqueous extract of henna leaves is shown in Figure 9. The peaks appear at the wavelength of $384 \mathrm{~nm}$ and $516 \mathrm{~nm}$. The UV-Visible absorption spectrum of an aqueous solution containing extract of henna leaves and ferrous ion (freshly prepared solution of ferrous sulphate) is shown in Figure 10. A peak appears at the wavelength of $396 \mathrm{~nm}$. The spectra reveal that there is shift in the position of the peak and the absorbance value also changes. It predicts the formation of complex in the solution.

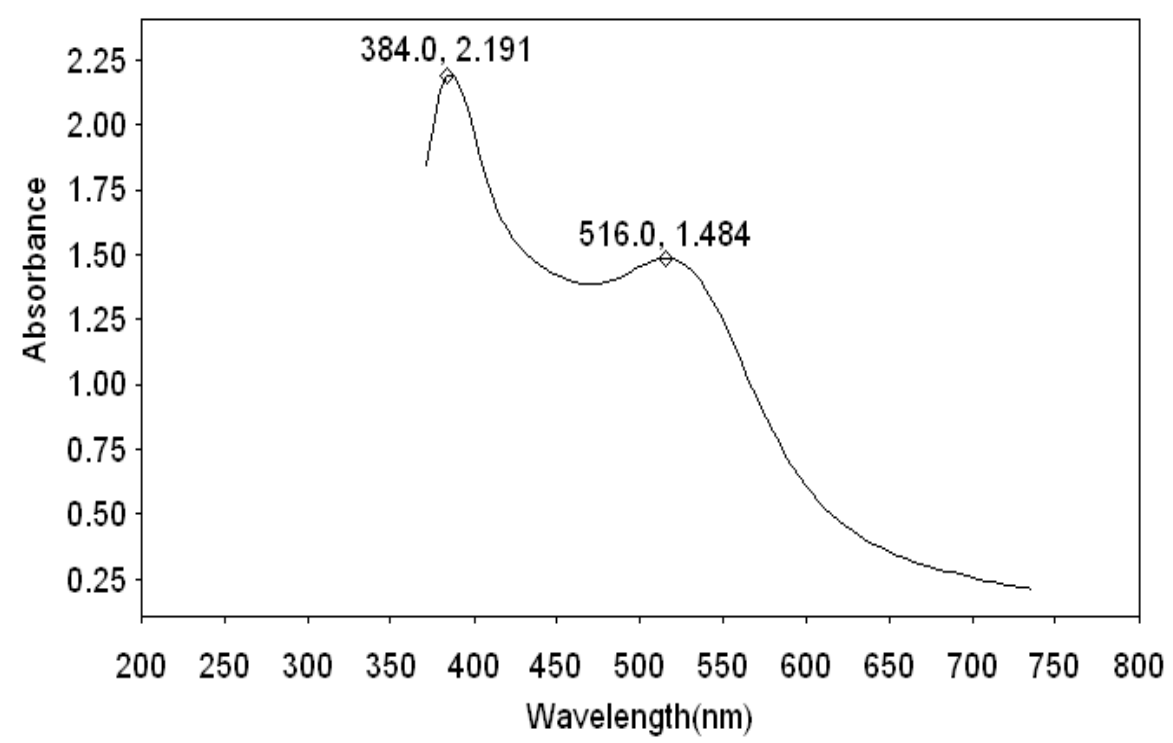

Figure 9. UV-Visible spectrum of an aqueous extract of henna leaves.

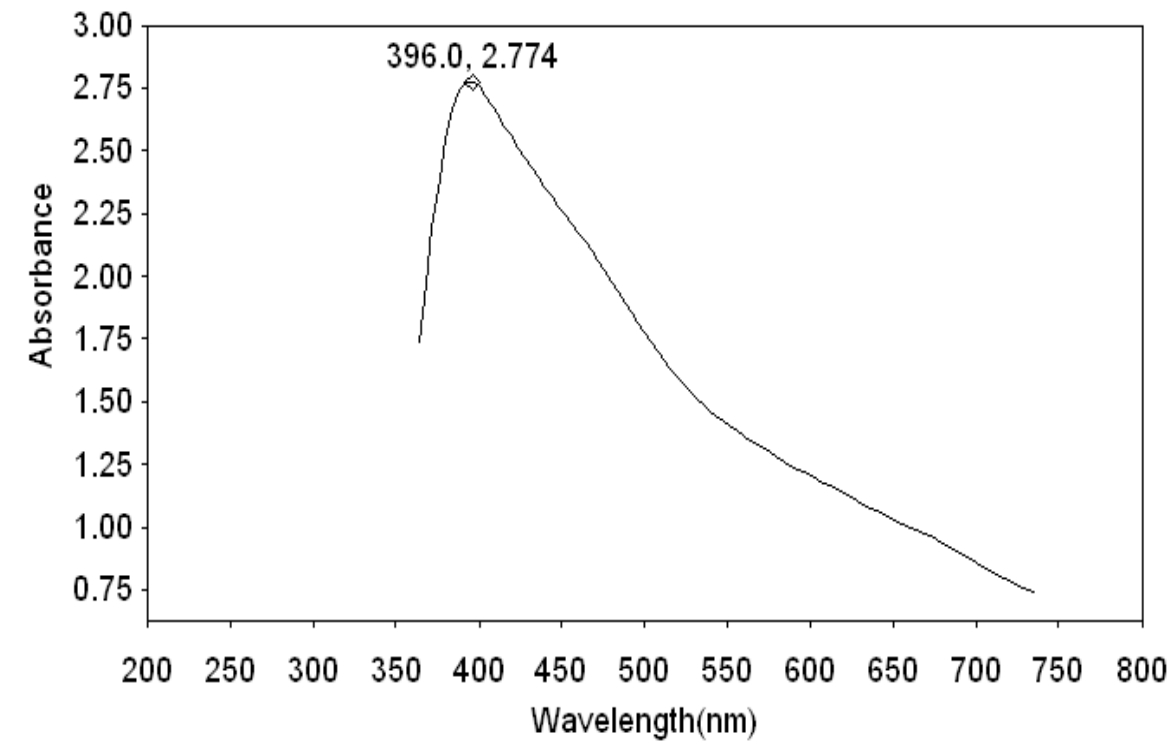

Figure 10. UV-Visible spectrum of an aqueous extract of henna leaves and ferrous ion. 
Analysis of fluorescence spectra

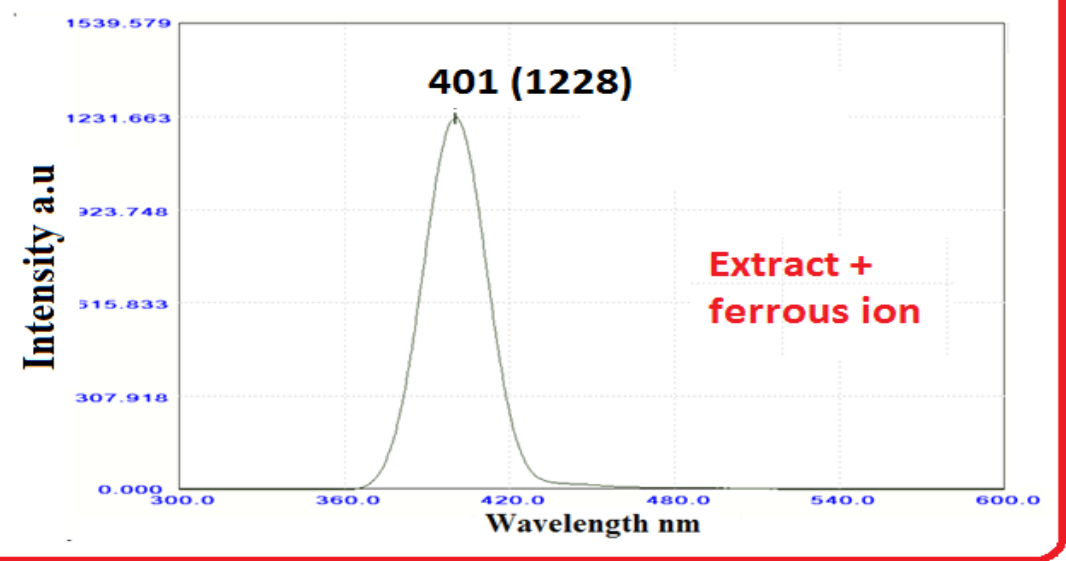

Figure 11. Fluorescence spectrum $\left(\lambda_{\mathrm{ex}}=396 \mathrm{~nm}\right)$ of an aqueous solution containing Ferrous ion and inhibitor (AEHL) solution.

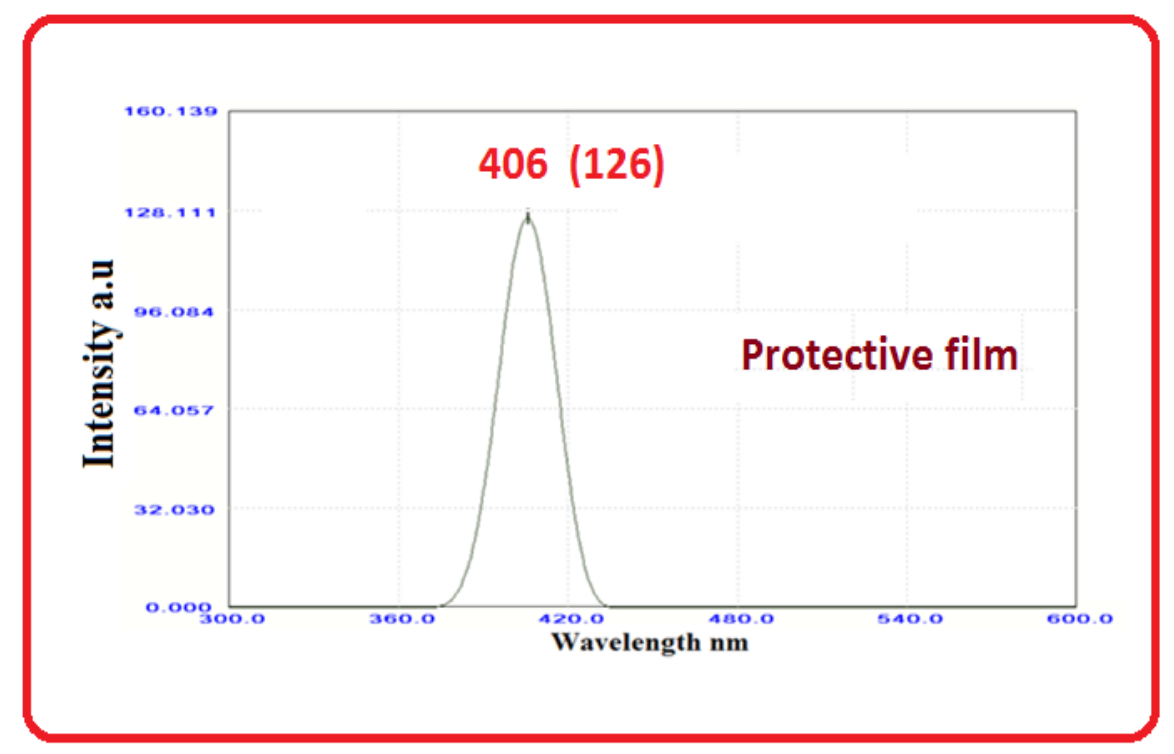

Figure 12. Fluorescence spectrum $\left(\lambda_{\mathrm{ex}}=396 \mathrm{~nm}\right)$ of film formed on the mild steel surface immersed in well water medium in presence of inhibitor (AEHL).

Fluorescence spectra have been employed in the field of corrosion inhibition studies [31]. The fluorescence spectrum $\left(\lambda_{\text {ex }}=396 \mathrm{~nm}\right)$ of a solution containing ferrous ion $\left(\mathrm{Fe}^{2+}\right)$ and an aqueous extract of henna leaves is shown in Figure 11. A peak appears at the wavelength of $401 \mathrm{~nm}$ and the intensity of the peak is 1228 a.u. (arbitrary units). This peak is due to the formation of iron-lawsone complex in solution. The fluorescence spectrum $\left(\lambda_{\mathrm{ex}}=396 \mathrm{~nm}\right)$ of the film formed on the mild steel surface after immersion in the solution containing of well water and henna leaves extract (AEHL) is given in Figure 12. A peak 
appears at the wavelength of $406 \mathrm{~nm}$ and the intensity of the peak is 126 a.u. This peak coincides with the peak of iron-lawsone complex. Thus it is concluded that the protective layer consists of iron- lawsone complex formed on the mild steel surface. It is revealed from the results that the intensity of the peak related to protective film on mild steel is considerably lower (126 a.u.) than the intensity of the peak associated with the ferrous ion solution in presence of inhibitor (1228 a.u.). The difference in the intensity of the peak can be explained by the reason that in the solid phase (protective layer) the electronic transition is constrained than in the liquid phase (ferrous ion and inhibitor solution). So the intensity of peak significantly decreases in the protective layer.

Analysis of FTIR spectra

The active principle of henna leaves extract is lawsone (Figure 13).

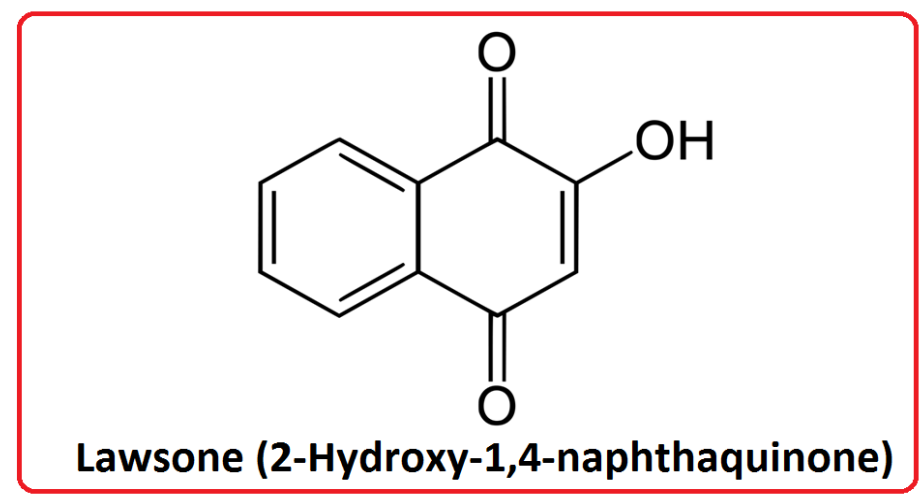

Figure 13. Structure of Lawsone.

FTIR spectra have been used in the study of corrosion inhibition to examine the protective film formed on the mild steel surface [31]. A small amount of AEHL was dried on a glass plate in the open air. A dried solid mass was collected. It was blended with potassium bromide and converted into pellet. The pellet was used for the FTIR study. The FTIR spectrum is shown in Figure 14. The stretching frequency due to $\mathrm{OH}$ group appears at $3409.24 \mathrm{~cm}^{-1}$. The stretching frequency due to $\mathrm{C}=\mathrm{O}$ group appears at $1776.17 \mathrm{~cm}^{-1}$. The stretching frequency due to $\mathrm{C}=\mathrm{C}$ group appears at $1624.44 \mathrm{~cm}^{-1}$. Thus the structure of the active ingredient (lawsone) (Figure 13) of henna leaves extract (AEHL) is confirmed by FTIR spectrum.

The FTIR spectrum of the protective film formed on the mild steel surface after immersion in the solution containing $90 \mathrm{~mL}$ of well water and $10 \mathrm{~mL}$ of inhibitor solution (AEHL) is shown in Figure 15. It is noted that the stretching frequency due to $\mathrm{OH}$ group has shifted to $3416.32 \mathrm{~cm}^{-1}$. The stretching frequency due to $\mathrm{C}=\mathrm{O}$ has shifted to $1797.66 \mathrm{~cm}^{-1}$. The stretching frequency due to $\mathrm{C}=\mathrm{C}$ has shifted to $1633.01 \mathrm{~cm}^{-1}$. Thus it is found that lawsone has bonded with ferrous ion through polar atoms namely oxygen. It is concluded that the protective film consists of iron-lawsone complex. The stretching frequencies of different functional groups present in lawsone are summarized in Table 7. 


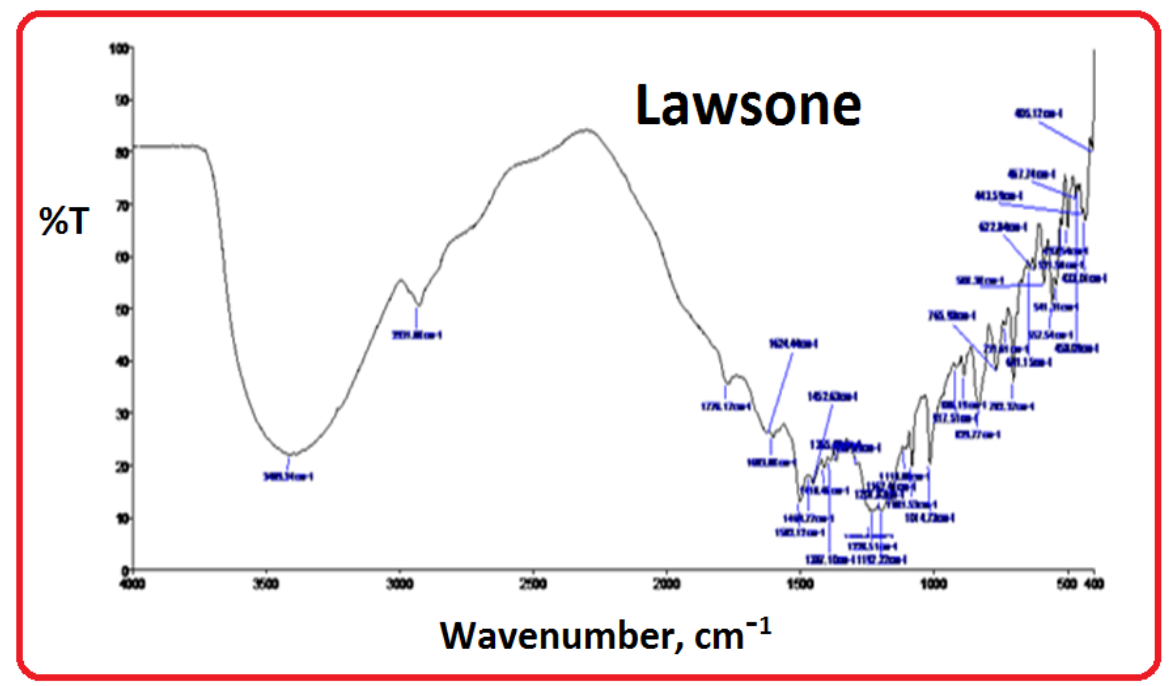

Figure 14. FTIR Spectrum of lawsone.

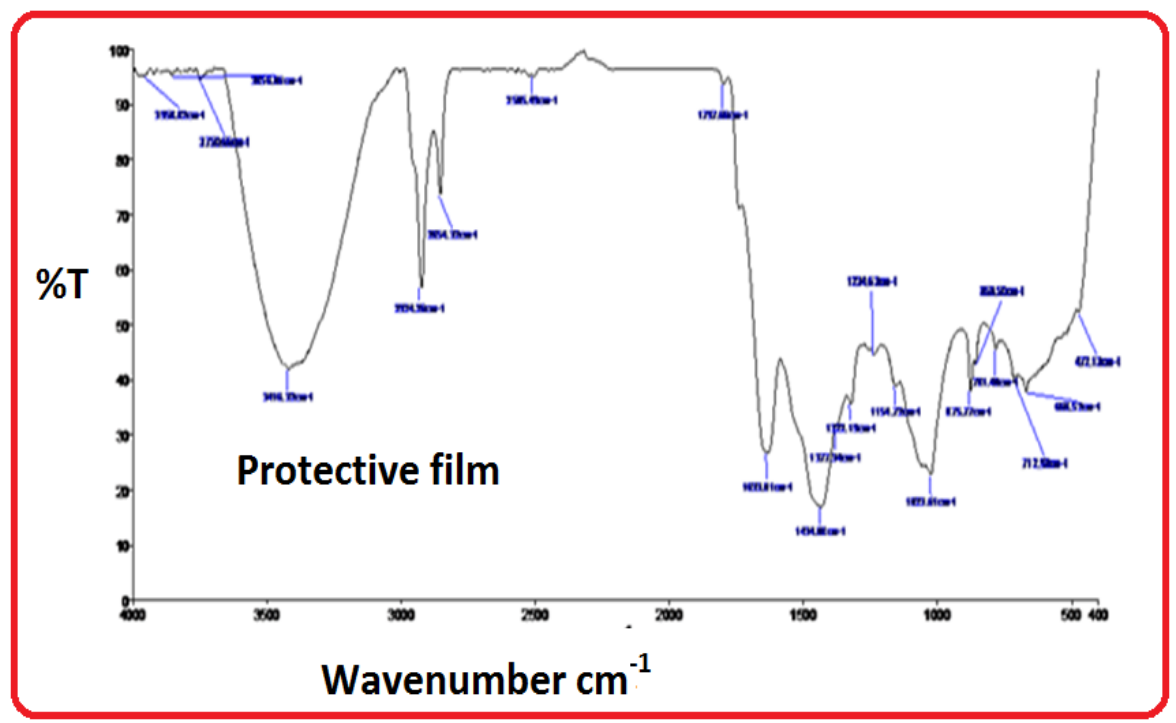

Figure 15. FTIR spectrum of film formed on mild steel immersed in well water and extract.

Table 7. The stretching frequencies of different functional groups present in inhibitor (AEHL).

\begin{tabular}{cccc}
\hline & & \multicolumn{2}{c}{${\text { Stretching frequency, } \mathbf{~ c m}^{-\mathbf{1}}}$} \\
\cline { 3 - 4 } No. & Various functional groups & $\begin{array}{c}\text { Active ingredient in } \\
\text { inhibitor (AEHL) } \\
\text { (Lawsone) }\end{array}$ & $\begin{array}{c}\text { Protective film formed on the } \\
\text { mild steel surface }\end{array}$ \\
\hline 1 & $\mathrm{OH}$ & 3409.24 & 3416.32 \\
2 & $\mathrm{C}=\mathrm{O}$ & 1776.17 & 1797.66 \\
3 & $\mathrm{C}=\mathrm{C}$ & 1624.44 & 1633.01 \\
\hline
\end{tabular}




\section{Analysis of SEM Studies}

SEM image is employed in the analysis of surface morphology of the protective film formed on the metal surface during corrosion inhibition study [31]. The SEM images of various metal surfaces are shown in Figure 16.

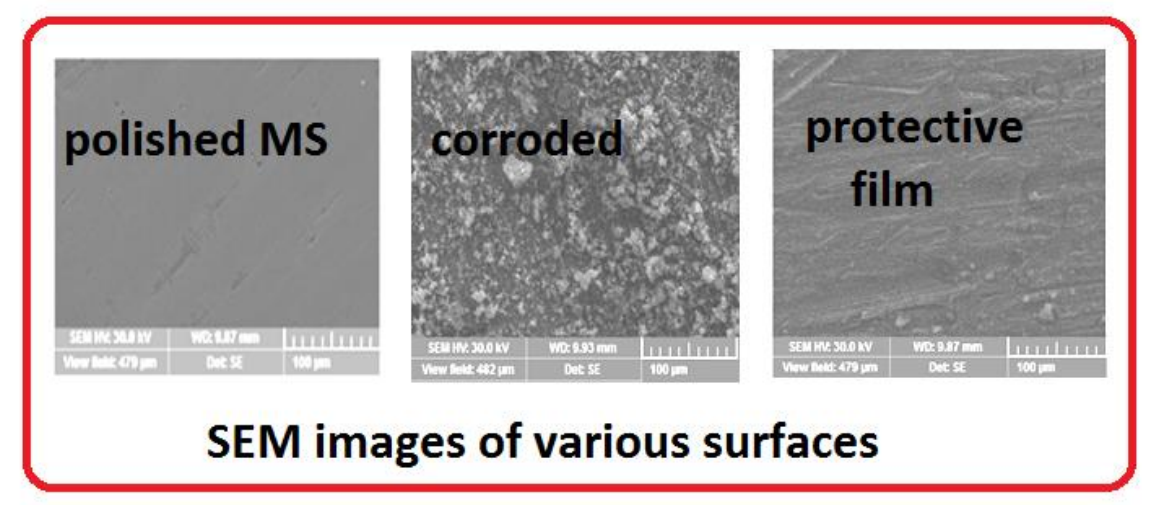

Figure 16. SEM images of various surfaces.

The SEM images of polished mild steel, polished mild steel immersed in well water medium mild steel immersed in well water in presence of inhibitor (AEHL) are shown in Figure 16.

The SEM image of polished mild steel appears to be smooth. The SEM image of the mild steel in well water environment seems to be rough. The noticeable cavities are present on the corroded mild steel surface. The SEM image of the mild steel in well water containing inhibitor (AEHL) appears to be significantly smooth than the well water medium. Thus the SEM study reveals that the mild steel surface is protected by the formation of non-porous smooth thin film in the presence of inhibitor (AEHL).

\section{Analysis of AFM (Atomic Force Microscopy) studies}

Atomic force microscopy is used to analyze the surface morphology of the testing specimen [32]. The two-dimensional and the three-dimensional AFM images of polished mild steel surface, mild steel immersed in well water environment and the mild steel immersed in well water in presence of inhibitor (AEHL) are shown in Figures 17 and 18. Statistical roughness parameters obtained from AFM studies such as RMS $\left(R_{\mathrm{q}}\right)$ roughness $(\mathrm{nm})$, Average $\left(R_{\mathrm{a}}\right)$ roughness $(\mathrm{nm})$ and maximum peak-to-valley height $(\mathrm{nm})$ are summarized in Table 8 and Figure 19.

It is observed from the Table 7 that the AFM parameters associated with statistical roughness such as the RMS roughness, average roughness and maximum peak-to-valley height of polished mild steel surface is very low. The values are significantly very high for mild steel surface in well water medium (corroded surface). In the case of mild steel in well water medium in presence of inhibitor (AEHL) the values are somewhat higher than that of polished mild steel and considerably lower than that of the mild steel in well water medium 
(corroded surface) (Figure 19). These results reveal that a thin protective film is formed on the mild steel surface and prevents the mild steel from corrosion.

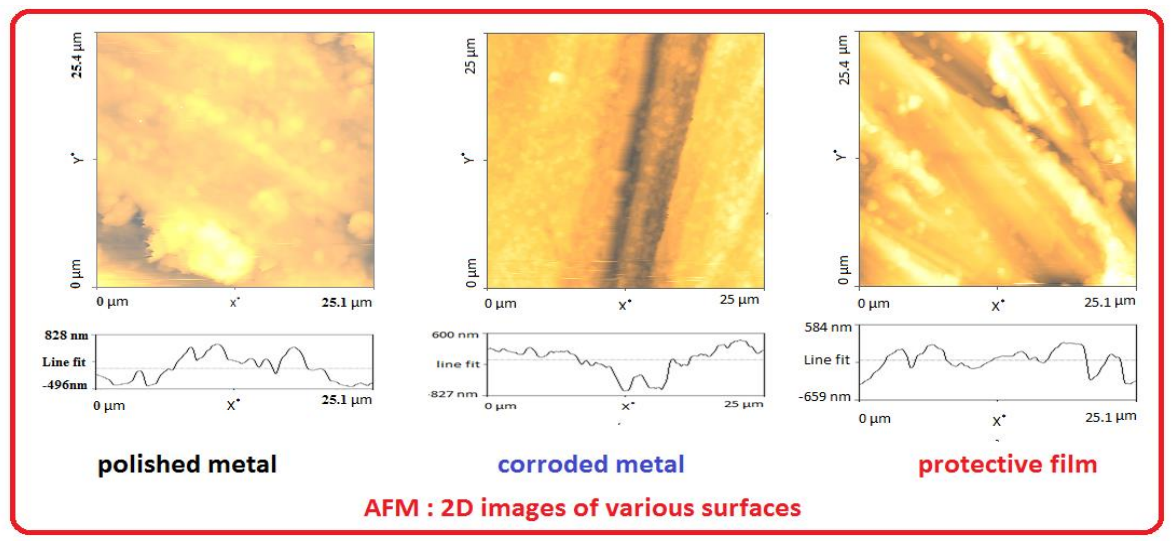

Figure 17. AFM-2D images of various surfaces. Three-dimensional AFM images (a) Polished mild steel, (b) Mild steel in well water environment, (c) Mild steel in well water in presence of inhibitor (AEHL).

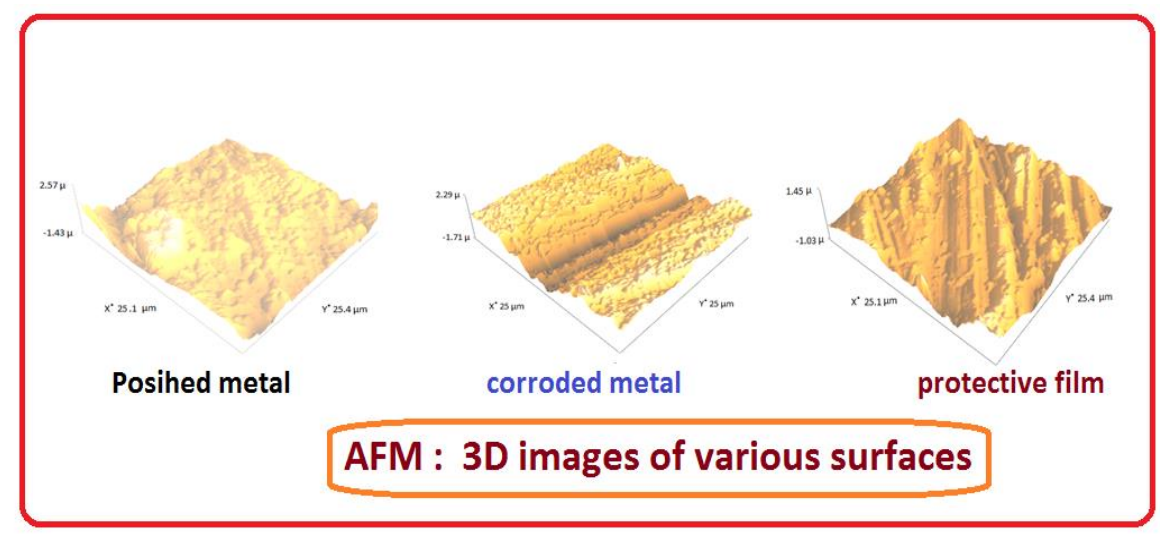

Figure 18. AFM-3D images of various surfaces.

Table 8. AFM parameters of mild steel in the presence and absence of inhibitor (AEHL).

\begin{tabular}{cccc}
\hline Surfaces & $\begin{array}{c}\mathbf{R M S}\left(\boldsymbol{R}_{\mathbf{q}}\right), \\
\text { Roughness }(\mathbf{n m})\end{array}$ & $\begin{array}{c}\text { Average }\left(\boldsymbol{R}_{\mathbf{a}}\right), \\
\text { Roughness (nm) }\end{array}$ & $\begin{array}{c}\text { Maximum peak- } \\
\text { to-valley height } \\
(\mathbf{n m})\end{array}$ \\
\hline Polished mild steel & 135.9 & 172.84 & 806.9 \\
Mild steel in well water and extract & 167.36 & 198.53 & 846.95 \\
Mild steel in well water & 513.53 & 637.27 & 2885.3 \\
\hline
\end{tabular}




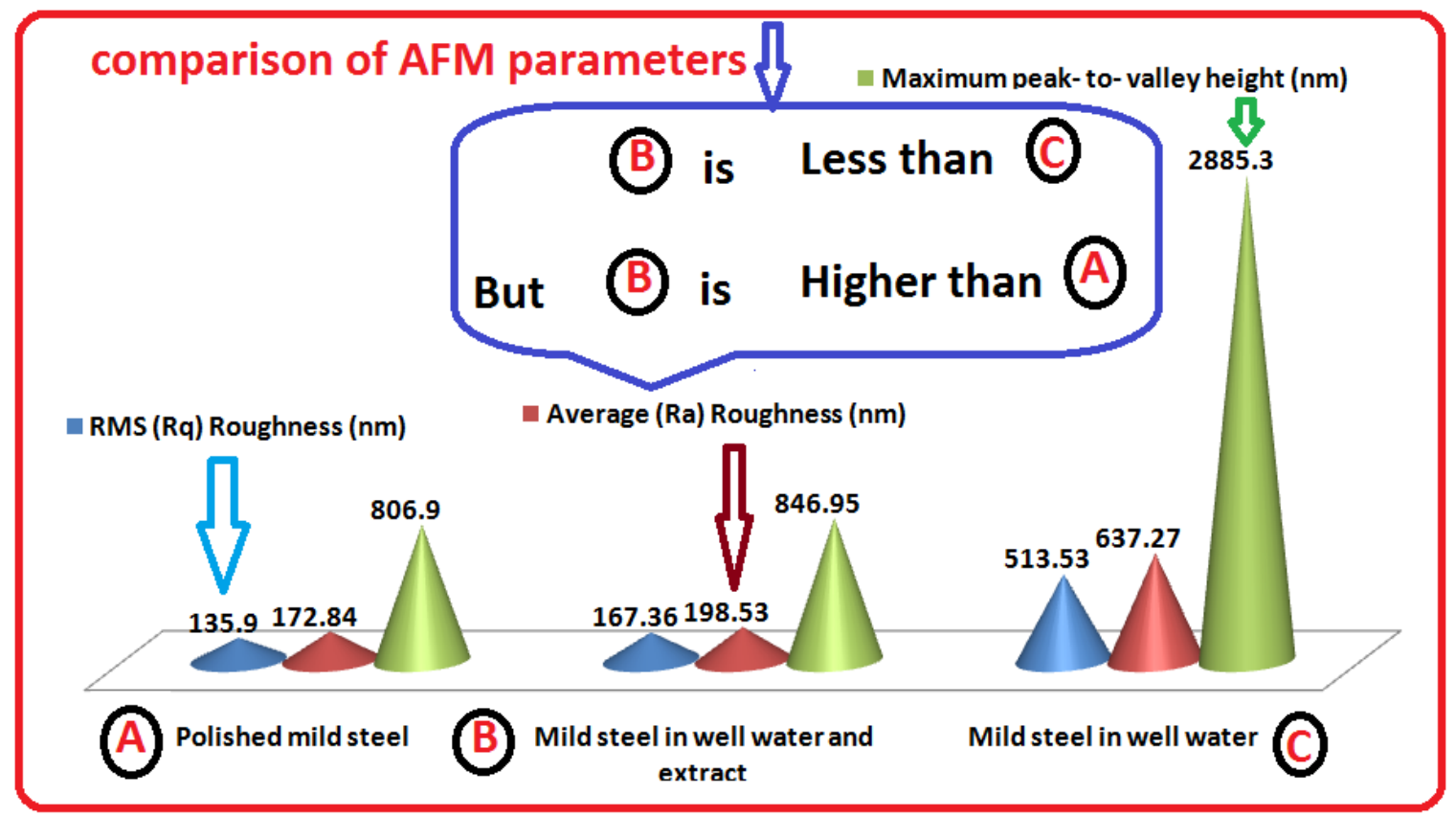

Figure 19. Comparison of AFM parameters of various surfaces.

\section{Conclusions}

The present case study leads to the following conclusions:

- An aqueous extract of henna leaves (Lawsonia inermis) has been used as corrosion inhibitor in controlling corrosion of mild steel in well water.

- The inhibition efficiency has been evaluated by weight loss method.

- The mechanistic aspects of corrosion inhibition have been studied by electrochemical studies such as polarization study and AC impedance spectra.

- The protective film formed on the metal surface has been analysed by luminescence spectra, FTIR, SEM and AFM.

- The protective film consists of iron-lawsone complex.

- The adsorption of inhibitor molecules on the metal surface obeys Langmuir adsorption isotherm.

\section{Acknowledgment}

The authors are thankful to their respective managements for their help and encouragement. Special thanks to Rev. Dr. Antony Pushpa Ranjitham (Superior General), Rev. Sr. Thanaseeli Sengole (Asst. General), Rev. Sr. M. Margaret Inbaseeli (College Secretary), Rev. Dr. Pramila (Principal), Rev. Sr. Gnana Soundari (Provincial) and Mrs J. Antony Justina Mary (Vice Principal) for their Prayer and Blessings. 


\section{References}

1. P.R. Sivakumar and A.P. Srikanth, Green corrosion inhibitor: A comparative study, Sadhana Acad. Proc. Eng. Sci., 2020, 45, no. 1, 56.

2. A. Dehghani, G. Bahlakeh, B. Ramezanzadeh and M. Ramezanzadeh, Potential role of a novel green eco-friendly inhibitor in corrosion inhibition of mild steel in $\mathrm{HCl}$ solution: Detailed macro/micro-scale experimental and computational explorations, Constr. Build. Mater., 2020, 245, 118464.

3. A. Dehghani, G. Bahlakeh, B. Ramezanzadeh and M. Ramezanzadeh, Experimental complemented with microscopic (electronic/atomic)-level modeling explorations of Laurus nobilis extract as green inhibitor for carbon steel in acidic solution, J. Ind. Eng. Chem., 2020, 84, 52-71. doi: 10.1016/j.jiec.2019.12.019

4. M.T. Majd, M. Ramezanzadeh, G. Bahlakeh and B. Ramezanzadeh, Probing molecular adsorption/interactions and anti-corrosion performance of poppy extract in acidic environments, J. Mol. Liq., 2020, 304, 112750.

5. A.O. Yüce, Corrosion inhibition behavior of Robinia pseudoacacia leaves extract as a eco-friendly inhibitor on mild steel in acidic media, Met. Mater. Int., 2020, 26, no. 4, 456-466. doi: 10.1007/s12540-019-00509-7

6. L. Ghalib, H.A. Abdulghani and A.J. Hamad, A comparative study on inhibitory action of Ficus carica, Olea europaea and Ziziphus spina-christi plant leaves on carbon steel in sulfuric acid medium, AIP Conference Proceedings, 2020, 2213, 020180.

7. Supriya Bangera, Vijaya D.P. Alva, Aqueous extract of Macaranga Peltata leaves green corrosion inhibitor for mild steel in hydrochloric acid medium, Surf. Eng. Appl. Electrochem., 2020, 56, no. 2, 259-266. doi: 10.3103/S1068375520020040

8. Elfidiah, D. Kharismadewi and E. Yuliwati, Wuluh star fruit (Averrhoa bilimbi linn.) leaves extract as green corrosion inhibitor in reinforced steel, J. Phys.: Conf. Ser., 2020, 1444, no. 1, 012003.

9. M. Barbouchi， B. Benzidia， M.E. Idrissi and M. Choukrad，Iron corrosion green inhibition in a $3 \% \mathrm{NaCl}$ solution, by leaves extract from pistacia terebinthus $L$. growing wild in Morocco, Port. Electrochim. Acta, 2020, 38, no. 3, 175-184. doi: 10.4152/pea.202003175

10. B. Durvas Seshian, B.R. Pandian and U. Durai, Adina Cordifolia as a corrosion inhibitor - a green approach against mild steel corrosion in $0.5 \mathrm{M}$ sulphuric acid medium, Pigm. Resin Technol., 2020, 49, no. 1, 63-70. doi: 10.1108/PRT-01-2019-0004

11. M. Ben Harb, S. Abubshait, N.Etteyeb, M. Kamoun and A. Dhouib, Olive leaf extract as a green corrosion inhibitor of reinforced concrete contaminated with seawater, Arabian J. Chem., 2020, 13, no. 3, 4846-4856. doi: 10.1016/j.arabjc.2020.01.016

12. S. Chen, B. Zhu and X. Liang, Corrosion inhibition performance of coconut leaf extract as a green corrosion inhibitor for X65 steel in hydrochloric acid solution, Int. J. Electrochem. Sci., 2020, 15, no. 1, 1-15. doi: 10.20964/2020.01.39 
13. A.M. Abdel-Gaber, H.T. Rahal and F.T. Beqai, Eucalyptus leaf extract as a eco-friendly corrosion inhibitor for mild steel in sulfuric and phosphoric acid solutions, Int. J. Ind. Chem., 2020, 11, no. 2, 123-132. doi: 10.1007/s40090-020-00207-z

14. O.O. Ogunleye, A.O. Arinkoola, O.A. Eletta, A.F. Morakinyo and J.O. Hamed, Green corrosion inhibition and adsorption characteristics of Luffa cylindrica leaf extract on mild steel in hydrochloric acid environment, Heliyon, 2020, 6, no. 1, e03205. doi: 10.1016/j.heliyon.2020.e03205

15. M. Tabatabaei majd, R. Naderi and B. Ramezanzadeh, Promotion of the active/barrier protection function of epoxy ester coating/steel system utilizing differently synthesized hybrid pigment through zinc acetylacetonate tailored with green inhibitor molecules, Prog. Org. Coat., 2020, 138, 105380. doi: 10.1016/j.porgcoat.2019.105380

16. I. Ekere, O. Agboola and S. Eshorane Sanni, DNA from plant leaf Extracts: A review for emerging and promising novel green corrosion inhibitors, J. Phys.: Conf. Ser., 2019, 1378, no. 2, 022049. doi: 10.1088/1742-6596/1378/2/022049

17. G.A. Nchewi, L.N. Okoro, F.V.Adams and B.O. Agboola, Corrosion inhibition efficiency of Tamarindus Indica leaves extracts on mild steel in hydrochloric acid, $J$. Phys.: Conf. Ser., 2019, 1378, no. 2, 022051. doi: 10.1088/1742-6596/1378/2/022051

18. A. Dehghani, G.Bahlakeh and B. Ramezanzadeh, Green Eucalyptus leaf extract: A potent source of bio-active corrosion inhibitors for mild steel, Bioelectrochemistry, 2019, 130, 107339. doi: 10.1016/j.bioelechem.2019.107339

19. P. Muthukrishnan, P. Prakash, B. Jeyaprabha and K. Shankar, Stigmasterol extracted from Ficus hispida leaves as a green inhibitor for the mild steel corrosion in $1 \mathrm{M} \mathrm{HCl}$ solution, Arabian J. Chem., 2019, 12, no. 8, 3345-3356. doi: 10.1016/j.arabjc.2015.09.005

20. M. Tabatabaei majd, G. Bahlakeh, A. Dehghani, B. Ramezanzadeh and M. Ramezanzadeh, Combined molecular simulation, DFT computation and electrochemical studies of the mild steel corrosion protection against $\mathrm{NaCl}$ solution using aqueous Eucalyptus leaves extract molecules linked with zinc ions, J. Mol. Liq., 2019, 294, 111550. doi: 10.1016/j.molliq.2019.111550

21. R. Nagalakshmi, L. Nagarajan, R.J. Rathish, S.S. Prabha, N. Vijaya, J. Jeyasundari and S. Rajendran, Int. J. Nano. Corr. Sci. Engg., 2014, 1, 39.

22. J.A. Thangakani, S. Rajendran, J. Sathiabama, R.M. Joany, R.J. Rathis and S.S. Prabha, Int. J. Nano. Corr. Sci. Engg., 2014, 1, 50.

23. A. Nithya, P. Shanthy, N. Vijaya, R.J. Rathish, S.S. Prabha, R.M. Joany and S. Rajendran, Int. J. Nano Corr. Sci. Engg., 2015, $2,1$.

24. A.C.C. Mary, S. Rajendran, H. Al-Hashem, R.J. Rathish, T. Umasankareswari and J. Jeyasundari, Int. J. Nano Corr. Sci. Engg., 2015, 1, 42.

25. A. Anandan, S. Rajendran, J. Sathiyabama and D. Sathiyaraj, Int. J. Corros. Scale Inhib., 2017, 6, no. 2, 132-141. doi: 10.17675/2305-6894-2017-6-2-3 
26. C.O. Akalezi, C.E. Ogukwe, E.A. Ejele and E.E. Oguzie, Int. J. Corros. Scale Inhib., 2016, 5, no. 2, 132-146. doi: 10.17675/2305-6894-2016-5-2-3

27. T.A. Onat, D. Yiğit, H. Nazır, M. Güllü and G. Dönmez, Int. J. Corros. Scale Inhib., 2016, 5, no. 3, 273-281. doi: 10.17675/2305-6894-2016-5-3-7

28. A.S. Fouda, M.A. El-Morsy, A.A. El-Barbary and L.E. Lamloum, Int. J. Corros. Scale Inhib., 2016, 5, no. 2, 112-131. doi: 10.17675/2305-6894-2016-5-2-2

29. V.I. Vigdorovich, L.E. Tsygankova, E.D. Tanygina, A.Yu. Tanygin and N.V. Shel, Int. J. Corros. Scale Inhib., 2016, 5, no. 1, 59-65. doi: 10.17675/2305-6894-2016-5-1-5

30. P.N. Devi, J. Sathiyabama and S. Rajendran, Int. J. Corros. Scale Inhib., 2017, 6, no. 1, 18-31. doi: 10.17675/2305-6894-2017-6-1-2

31. P. Mahalakshmi, S. Rajendran, G. Nandhini, S.C. Joycee, N. Vijaya, T. Umasankareswari and N. Renuga Devi, Inhibition of corrosion of mild steel in sea water by an aqueous extract of turmeric powder, Int. J. Corros. Scale Inhib., 2020, 9, no. 2, 706-725. doi: 10.17675/2305-6894-2020-9-2-20

32. V.P. Grigor'ev, E.V. Plekhanova, E.G. Drogan, L.D. Popov and T.G. Plekhanova, Inhibiting action of amino-heterocyclic compounds under conditions of iron corrosion in sulfuric acid solutions, Int. J. Corros. Scale Inhib., 2020, 9, no. 2, 584-594. doi: $\underline{10.17675 / 2305-6894-2020-9-2-13}$ 